\title{
Sensitivity Analysis of the Effects of Climate Change on Streamflow Using Climate Elasticity in the Luan River Basin, China
}

\author{
Hui Wang ${ }^{1,2}$, Kangning $\mathrm{He}^{1,2 *}$ \\ ${ }^{1}$ Beijing Forestry University, Key Laboratory of State Forestry Administration on Soil and Water Conservation, \\ Beijing 100083, China \\ ${ }^{2}$ Beijing Forestry University, Engineering Research Center of Forestry Ecological Engineering, \\ Ministry of Education, Beijing 100083, China
}

Received: 25 July 2016

Accepted: 3 November 2016

\begin{abstract}
Streamflow depends directly on climate conditions (e.g., precipitation and potential evapotranspiration, or $\mathrm{E}_{\mathrm{p}}$ ), which affect water balance at the basin scale. The present study was conducted to investigate the impact of climate change on streamflow in the Luan River basin, China. To assess the impact of climatic variation on streamflow, the temporal trends of streamflow were explored using the Mann-Kendall method and the sensitivities of streamflow to precipitation, potential evapotranspiration, and the aridity index were evaluated with the modified method of climate elasticity. The results showed that the average coefficients of sensitivity of streamflow to precipitation and potential evapotranspiration were 3.23 and -2.23 , respectively, indicating that a $10 \%$ increase in precipitation or potential evapotranspiration would lead to a $32.3 \%$ increase or a $22.3 \%$ decrease in streamflow, respectively. Additionally, the average coefficient of sensitivity of streamflow to the aridity index was -2.53 , which indicated that streamflow would decrease by $25.3 \%$ with a $10 \%$ increase in the aridity index. The average coefficients of the sensitivity of streamflow to climatic variation appeared to have an inverse relationship with the runoff coefficient, showing that the lower the streamflow of the basin became, the more sensitive the streamflow would be with respect to climatic variation.
\end{abstract}

Keywords: climate change, climate elasticity, Luan River basin, streamflow

\section{Introduction}

Natural streamflow is the main source of surface water and plays an important role in agricultural irrigation, socioeconomic development, and local eco-environmental

*e-mail: hkn1962@126.com conservation at the basin level. The Luan River basin is a sub-basin of the Hai River in northern China. This basin is an important economic centre of China and has a key role in the sustainable development of the economy and ecology. To alleviate water shortages in Tianjin and Tangshan, the Panjiakou and Daheiting Reservoir system, which is the primary water source for these two cities, was constructed in the 1980 s to supply water to 6.5 million 
people. However, since 1988 the streamflow in this region has decreased by $30.8 \%$ [1], and the sharply increasing water shortages in this basin have hindered economic development and resulted in severe environmental and ecological problems [2]. Therefore, studying the variability of the streamflow in the Luan River basin is of great importance.

As an integrated part of the geophysical system, hydrological processes reflect the combined effects of soil, vegetation, and climate [3-5], and the resulting changes in streamflow at the basin scale [6-7]. Recent climate changes and human activity have led to massive changes in the hydrological processes and water availability in many basins worldwide [8-10]. Particularly in China, most rivers have shown a significant decrease in annual streamflow during the last 50 years [11-15]. To improve water resource management and planning, understanding the impact of climate change on water resources is becoming increasingly important.

For the past few years, investigations on the responses of hydrological processes to climate change have become increasingly common in China [2, 16-18]. For example, $\mathrm{Du}$ et al. [16] showed that the contribution of climate variation to streamflow reduction in a basin located in a humid region of South China was $47 \%$. Liu et al. [17] reported that climate variation contributed $68.8 \%$ to the decrease in streamflow in the Danjiangkou Reservoir basin and $31.5 \%$ to the decrease in streamflow in the Miyun Reservoir basin. Wang et al. [2] suggested that climate variability may be responsible for the decrease in the annual streamflow in the Hutuo River catchment.

To understand the influence of climate change on streamflow, various methods have been used to quantify the effect of climate variability on the changes in catchment streamflow. Of these methods, climate elasticity has been widely used in different regions of the world [11, 19-21]. To estimate the impact of climatic variation on streamflow, the climate elasticity method considers precipitation and potential evapotranspiration as representative indicators. The method based on the climate elasticity of streamflow proposed by Schaake [22] is simpler and has been tested and determined to be effective in several studies $[13,23-$ 24].

The current study primarily aims to identify the sensitivity of streamflow to climate change in the Luan River basin. First, we investigated the hydrological changes in the precipitation, evapotranspiration, and streamflow in the catchment. Then, the climate elasticity method was used to investigate the effect of climate change on streamflow in the Luan River basin.

\section{Materials and Methods}

\section{Study Area}

The Luan River is located at $39^{\circ} 10^{\prime}-42^{\circ} 30^{\prime} \mathrm{N}$ and $115^{\circ} 30^{\prime}-119^{\circ} 15^{\prime} \mathrm{E}$ and begins on the Mongolian Plateau, snakes through the Yan Mountains and the eastern Hebei Plain, and joins the Bohai Sea in Leting County. This 888 $\mathrm{km}$-long river is part of the Hai River basin and irrigates a land area of $45,000 \mathrm{~km}^{2}$. The entire Luan River basin has an average annual precipitation of $455 \mathrm{~mm}$, with approximately $75-85 \%$ of the annual total concentrated during the flood season from June to September. This region is characterized by a typical temperate continental climate with a mean annual temperature that ranges from 5 to $12^{\circ} \mathrm{C}$. The major types of land use and land cover in the Luan River basin include forest, agriculture, grassland, and urban areas [25]. Recently, the Luan River basin has been designated as an eco-environmentally fragile area in China due to the rapid growth of industrialization and urbanization in this region. Because the purpose of this study was to analyse the hydrological response to climate change, natu-

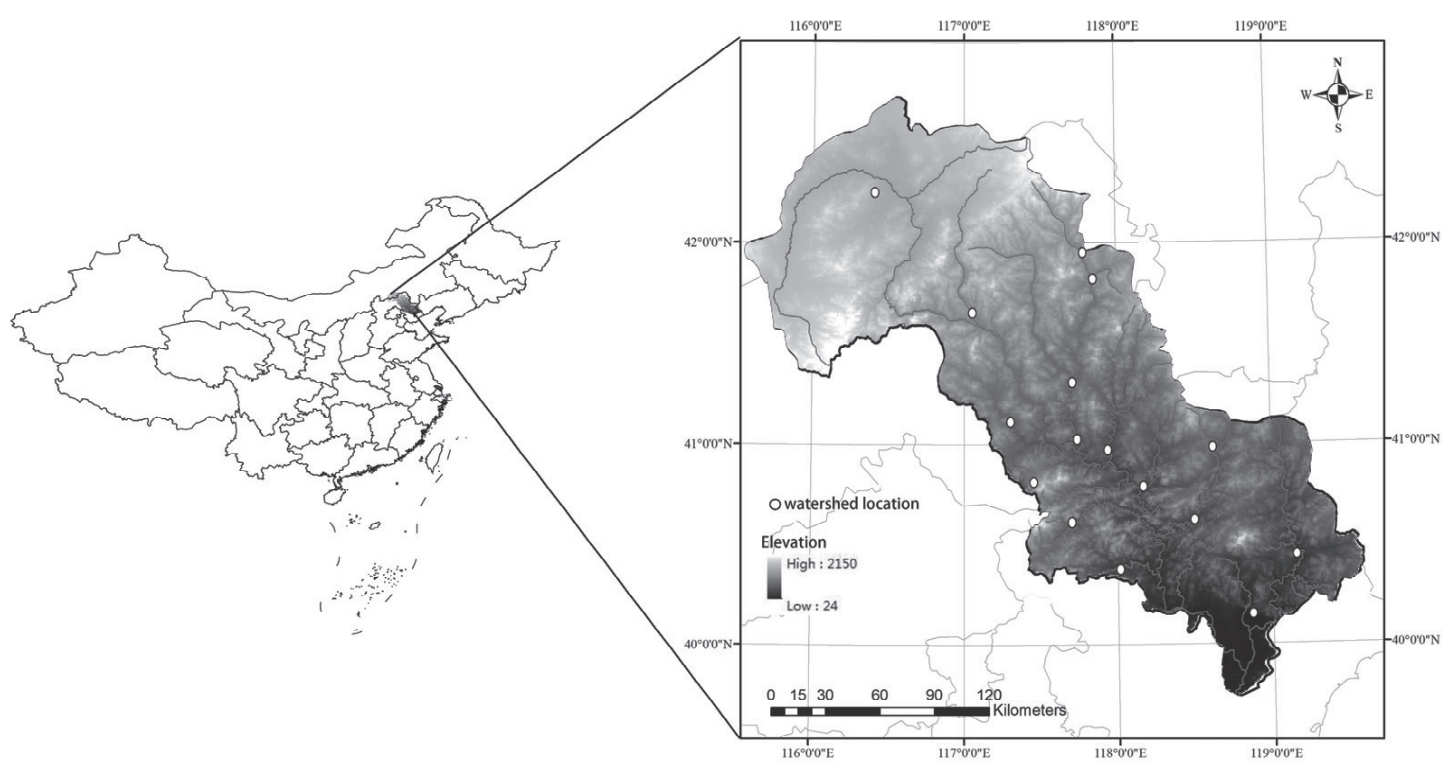

Fig. 1. Location of the study area and the hydrometeorological stations used in this study. 
Table 1. Characteristics of annual precipitation, potential evapotranspiration, and streamflow of the Luan River basin.

\begin{tabular}{|c|c|c|c|c|}
\hline Catchment & $\begin{array}{c}\text { Drainage area } \\
\left(\mathrm{km}^{2}\right)\end{array}$ & $\begin{array}{c}\text { Mean Annual Precipitation } \\
(\mathrm{mm})\end{array}$ & $\begin{array}{c}\text { Mean Annual Potential evapotranspiration } \\
(\mathrm{mm})\end{array}$ & $\begin{array}{c}\text { Mean Annual } \\
\text { Streamflow }(\mathrm{mm})\end{array}$ \\
\hline Dahekou & 999 & 390.51 & 937.4 & 71.14 \\
\hline Weichang & 997 & 435.27 & 893.8 & 39.9 \\
\hline Bianqiangshan & 562 & 441.91 & 922.8 & 44.44 \\
\hline Goutaizi & 1,890 & 467.02 & 964.3 & 47.05 \\
\hline Xiahenan & 2,404 & 502.23 & $1,056.4$ & 37.74 \\
\hline Boluonuo & 1,378 & 518.68 & $1,057.9$ & 54.26 \\
\hline Hanjiaying & 6,761 & 499.35 & 897.5 & 40.47 \\
\hline Chengde & 2,200 & 518.27 & $1,064.4$ & 85.48 \\
\hline Pingquan & 372 & 533.6 & $1,033.8$ & 68.43 \\
\hline Xiabancheng & 1,615 & 563.13 & 886.3 & 79.63 \\
\hline Liying & 568 & 632.92 & $1,022.8$ & 223.12 \\
\hline Kuancheng & 1,661 & 644.49 & 975.6 & 112.1 \\
\hline Hongqi & 714 & 767.8 & $1,040.2$ & $1,036.3$ \\
\hline Tumenzi & 2,822 & 638.72 & $1,060.9$ & 140.14 \\
\hline Lengkou & 538 & 705.84 & 894.7 & 112.73 \\
\hline Taolinkou & 5,250 & 691.49 & & 180.67 \\
\hline
\end{tabular}

ral streamflow data for 1960-2000 from 16 hydrological stations in the basin were used in the analyses. Luanhe watershed includes two dams (Daheiting and Taolinkou). To exclude anthropogenic interference on runoff, we located these two dams and necessarily ensured that they were not located in the 16 catchments we selected. The geographical distribution of these stations and their hydrological characteristics are shown in Fig. 1 and Table 1, respectively.

Data

The meteorological data used in this research, such as wind speed, relative humidity, and air temperature, were obtained from the China Meteorological Data Sharing Service System. All data for annual precipitation and streamflow during the period of 1960 to 2000 were obtained from the Hydrological Yearbook of the People's Republic of China; although they have not been published, the data are printed and issued for internal use. The boundaries of all catchments were delineated using the digital elevation model (DEM) with $90 \mathrm{~m}$ resolution from the Data Sharing Infrastructure of Earth System Science (www.geodata.cn).

\section{Methods}

\section{Potential Evapotranspiration}

The potential evapotranspiration $\left(\mathrm{E}_{\mathrm{p}}\right)$ was calculated according to the Penman equation [26-27] for each of the national weather stations within or around the study area from long-term (1960-2000) meteorological data. The equation has been used to optimally capture the dynamics in evaporative demand for a given land surface and climatic change [28]:

$E_{p}=E_{p R}+E_{p A}=\frac{\Delta}{\Delta+\gamma} R_{n}+\frac{\gamma}{\Delta+\gamma} \frac{6430\left(1+0.536 \mathrm{u}_{2}\right) \mathrm{D}}{\lambda}$

...where $\mathrm{E}_{\mathrm{p}}$ is potential evapotranspiration (mm day $\left.^{-1}\right) ; \mathrm{E}_{\mathrm{pR}}$ and $\mathrm{E}_{\mathrm{pA}}$ represent the radiative and aerodynamic components of the Penman equation, respectively; $\Delta$ is the slope of the saturation vapour pressure curve $\left(\mathrm{Pa} \mathrm{K}^{-1}\right)$; $\gamma$ is the psychrometric constant $\left(\mathrm{Pa} \mathrm{K}^{-1}\right) ; \mathrm{u}_{2}$ is the wind speed at $2 \mathrm{~m}$ height $\left(\mathrm{m} \mathrm{s}^{-1}\right) ; \lambda$ is the latent heat of vaporization of water $\left(2.45 \times 10^{6} \mathrm{~J} \mathrm{~kg}^{-1}\right)$; $\mathrm{D}$ is the vapour pressure deficit $(\mathrm{Pa})$; and $\mathrm{R}_{\mathrm{n}}$ is net radiation $\left(\mathrm{MJ} \mathrm{m}^{-2}\right.$ day $\left.^{-1}\right)$, which was calculated according to the approach of Yin et al. [29].

\section{Detection of Hydrological Changes}

To detect the long-term changes in climatic factors and streamflow, the widely used and tested Mann-Kendall method (M-K method), originally devised by Mann [30] and refined by Kendall [31], has been shown to be effective for the evaluation of the presence of a statistically significant trend in hydrological and climatological time series [32-34]. The Mann-Kendall test is based on the statistic S: 


$$
S=\sum_{i=1}^{N-1} \sum_{j=i+1}^{N} \operatorname{sign}\left(\mathrm{x}_{j}-\mathrm{x}_{i}\right)
$$

.... where $\mathrm{x}_{\mathrm{i}}$ and $\mathrm{x}_{\mathrm{j}}$ are two generic sequential values of the variable, $\mathrm{N}$ is the length of the data set, and the $\operatorname{sign}(\mathrm{X})$ takes the following values:

$$
\operatorname{sign}(\mathrm{X})=\left\{\begin{array}{lll}
+1 & \text { if } & X>0 \\
0 & \text { if } & X=0 \\
-1 & \text { if } & X<0
\end{array}\right.
$$

A positive value of $\mathrm{S}$ in Eq. (2) represents a positive trend in the observed data series, and vice versa. The null hypothesis $\mathrm{H}_{0}$ is that there is no trend in the dataset. The statistic $\mathrm{S}$ is approximately normally distributed with a mean of zero. For data sets with more than 10 values, the variance-associated statistic $\mathrm{S}(\operatorname{VAR}(S))$ can be calculated as follows:

$$
\operatorname{Var}(S)=\frac{n(\mathrm{n}-1)(2 \mathrm{n}+5)}{18}
$$

The values of $\mathrm{S}$ and $\operatorname{VAR}(S)$ are used to compute the test statistic $\mathrm{Z}$ as follows:

$$
Z= \begin{cases}\frac{S-1}{\sqrt{V A R(\mathrm{~S})}} & \text { if } \mathrm{S}>0 \\ 0 & \text { if } \mathrm{S}=0 \\ \frac{S+1}{\sqrt{V A R(\mathrm{~S})}} & \text { if } \mathrm{S}<0\end{cases}
$$

The presence of a statistically significant trend is assessed using the $Z$ value. A positive (negative) value for $\mathrm{Z}$ indicates an upward (downward) trend. $\mathrm{Z}$ has a normal distribution. $\mathrm{H}_{0}$ can be rejected at a significance level $\alpha$ if the absolute value of $Z$ is greater than $Z_{1-\alpha / 2}$, where $Z_{1-\alpha / 2}$ is obtained from the standard normal cumulative distribution tables [35]. In other words, the trend is significant at the set level of significance. Otherwise, no significant trend exists.

\section{Sensitivity Analysis Method}

In this study, we estimated the impact of climate change on streamflow using the climate elasticity method of streamflow proposed by Schaake [22]. The sensitivity coefficient $(\varepsilon)$ is defined by the proportional change in streamflow $(\mathrm{Q})$ divided by the proportional change in a climatic variable $(\mathrm{X})$, such as precipitation or potential evapotranspiration [34], and is expressed as follows:

$$
\varepsilon=\frac{\partial Q / Q}{\partial X / X}
$$

\section{The Sensitivity of Streamflow to Precipitation and Potential Evapotranspiration}

For unimpaired catchments with a streamflow that is not regulated or subject to diversion, the streamflow can be expressed as a function of climate variables without consideration of the catchment characteristics. The annual streamflow percentage change $(\Delta \mathrm{Q} / \mathrm{Q})$ was regarded as a function of the percentage change in the annual precipitation $(\Delta \mathrm{P} / \mathrm{P})$ and the potential evapotranspiration $\left(\Delta \mathrm{E}_{\mathrm{p}} / \mathrm{E}_{\mathrm{p}}\right)$ :

$$
\frac{\Delta Q}{\bar{Q}}=\varepsilon_{p} \frac{\Delta P}{\bar{P}}+\varepsilon_{E_{p}} \frac{\Delta E_{p}}{\bar{E}_{p}}
$$

There are interactions among individual climate variables, and such interactions may lead to inaccurate results. To solve this problem, Sun et al. [18] modified the climate elasticity of streamflow and found the modified climate elasticity to be more accurate and reasonable based on a correlation analysis. According to Sun et al. [18], the modified climate elasticity of a streamflow can be expressed as follows:

$$
\begin{aligned}
& \varepsilon_{p}=\operatorname{Median}\left(\frac{\Delta Q / \bar{Q}-\Delta E_{p} / \bar{E}_{p}}{\Delta P / \bar{P}-\Delta E_{p} / \bar{E}_{p}}\right), \\
& \varepsilon_{E_{p}}=\operatorname{Median}\left(\frac{\Delta P / \bar{P}-\Delta Q / \bar{Q}}{\Delta P / \bar{P}-\Delta E_{p} / \bar{E}_{p}}\right) .
\end{aligned}
$$

\section{The Sensitivity of the Streamflow to the Aridity Index}

Because precipitation and potential evapotranspiration are not totally independent, the aridity index $(\phi)$, which is the ratio between potential evapotranspiration and precipitation $\left(\phi=E_{p} / p\right)$, can be used as a representative indicator to estimate the impact of climatic variation in a streamflow with the climate elasticity method.

The Budyko hypothesis [36] states that actual evapotranspiration $\left(E_{a}\right)$ is a function of the aridity index and precipitation $\left(E_{a}=P \times f(\phi)\right)$. The long-term water balance can be used to derive the coefficient of the sensitivity of streamflow to the aridity index $\left(\varepsilon_{\phi}\right)$ as follows [17]:

$$
\varepsilon_{\phi}=-\frac{P}{Q}(1-f(\phi))-\frac{E_{P}}{Q} f^{\prime}(\phi)
$$

Essentially, a positive or negative sensitivity coefficient indicates that $\mathrm{Q}$ will increase or decrease as $\phi$ increases, 
respectively. Of the several forms of $f(\phi)$, the one proposed by Zhang et al. [37] was adopted for this study:

$$
f(\phi)=(1+\omega \phi) /(1+\omega \phi+1 / \phi)
$$

Here, $\omega$ is the plant-available water coefficient introduced by Zhang et al. [37] to reflect the difference in the way plants use soil water for transpiration due to the differences in the root system of different vegetation types; $\omega$ varies between 0.5 and 2.0 for the range of plants. In this study, the $\omega$ of each catchment was calculated through mean annual precipitation $(\mathrm{P})$, actual evapotranspiration $\left(\mathrm{E}_{\mathrm{T}}\right)$, and potential evapotranspiration $\left(\mathrm{E}_{\mathrm{p}}\right)$ by backcalculation using the equation introduced by Zhang et al. [37].

\section{Results}

\section{Hydrological Changes in the Study Area}

As shown in Fig. 2, we first calculated potential evapotranspiration according to the Penman equation [26-27] using long-term (1960-2000) meteorological data. Next, we simulated the potential evapotranspiration in the study area with the kriging interpolation method implemented in the ArcGIS software package. The most obvious indicators reflecting climatic characteristics are precipitation, temperature, and potential evapotranspiration. Fig. 3 shows the long-term variations in the annual precipitation $(\mathrm{P})$, temperature $(\mathrm{T})$, potential evapotranspiration $\left(\mathrm{E}_{\mathrm{p}}\right)$, and the streamflow $(\mathrm{Q})$ of the

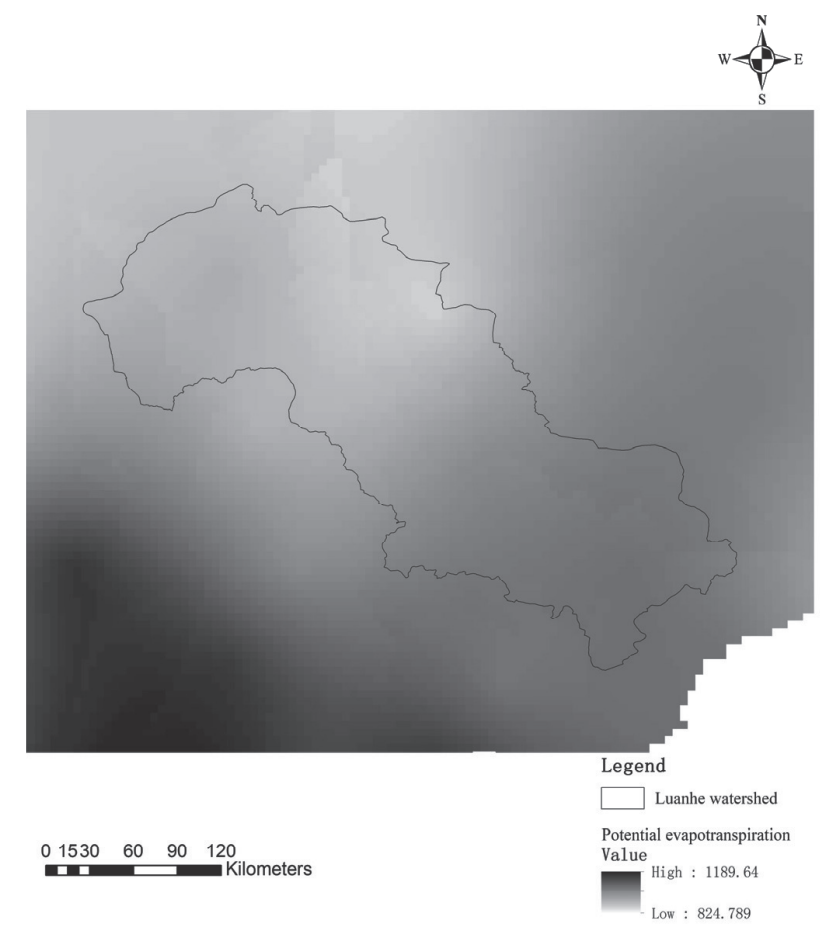

Fig. 2. Potential evapotranspiration in the Luan River basin.

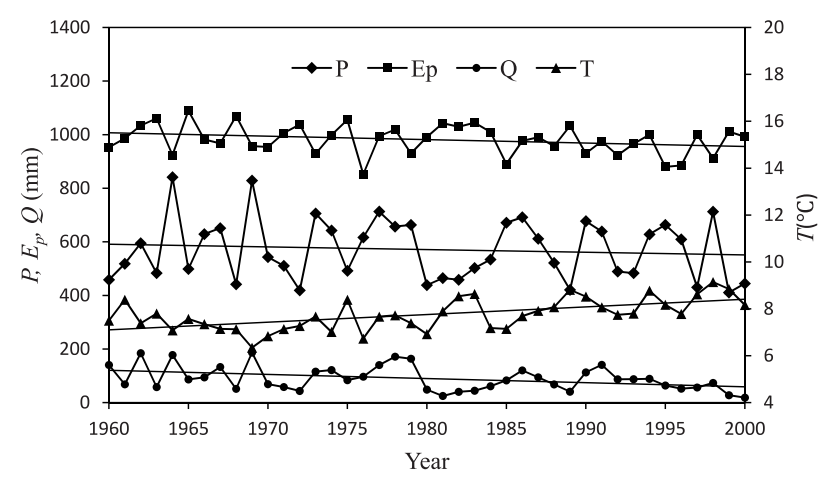

Fig. 3. Variations of the mean annual precipitation (P), temperature $(\mathrm{T})$, potential evapotranspiration $\left(\mathrm{E}_{\mathrm{p}}\right)$, and streamflow $(\mathrm{Q})$ for the Luan River basin from 1960 to 2000.

Luan River basin from 1960 to 2000. The long-term means (1960-2000) were $575.47 \mathrm{~mm}, 7.7^{\circ} \mathrm{C}, 977.03 \mathrm{~mm}$, and $94.55 \mathrm{~mm}$, respectively. As the results of the MannKendall trend test showed, the $\mathrm{Z}$ statistics for $\mathrm{P}, \mathrm{T}, \mathrm{E}_{\mathrm{p}}$, and Q were -1.143, 3.934, -0.859, and -3.266, respectively, which indicated that annual precipitation and potential evapotranspiration showed a downward trend, the annual temperature showed a significant upward trend, and a significant decreasing trend of the annual streamflow was evident in the study area, which indicated that climate change had truly occurred during the study period and affected streamflow in the study area. The aridity index of the Luan River basin, which is the ratio between potential evapotranspiration and precipitation $\left(\phi=E_{p} / p\right)$, ranged from 1.29 to 2.40 , with a mean of 1.81 .

\section{The Sensitivity of Streamflow to Precipitation and Potential Evapotranspiration}

To assess the impact of climate change on streamflow, most researchers $[20,23,38]$ have applied the concept of climate elasticity to investigate the streamflow response to climate change (e.g., precipitation and potential evapotranspiration). The sensitivity of streamflow to precipitation and potential evapotranspiration is determined using Eqs. 8 and 9, respectively. The precipitation and potential evapotranspiration elasticity of the catchments in the Luan River basin are listed in Table 2. The values of $\varepsilon_{\mathrm{p}}$ and $\varepsilon_{\text {Ep }}$ for the catchments were 1.70 to 5.05 and -0.70 to -4.05 , with means of 3.23 and $=2.23$, respectively. The signs of $\varepsilon_{\mathrm{p}}$ and $\varepsilon_{\mathrm{Ep}}$ indicate that the streamflow is expected to have a positive trend with an increase in precipitation but a negative trend with an increase in $\mathrm{E}_{\mathrm{p}}$. The findings also show that a $10 \%$ increase in $P$ would result in a $32.3 \%$ increase in streamflow, while a $10 \%$ increase in $\mathrm{E}_{\mathrm{p}}$ would induce a $22.3 \%$ decrease in streamflow.

A correlation analysis was used to further investigate the relationships between precipitation, potential evapotranspiration, and streamflow. As shown in Table 3, the positive correlation between precipitation and $\mathrm{Q}\left(\rho_{\mathrm{P}, \mathrm{Q}}\right)$ and the negative correlation between $\mathrm{E}_{\mathrm{p}}$ and $\mathrm{Q}\left(\rho_{\mathrm{Ep}, \mathrm{Q}}\right)$ are statistically significant at the 0.01 level, which suggests that 
Table 2. Elasticity of precipitation and potential evapotranspiration to streamflow.

\begin{tabular}{|c|c|c|}
\hline Catchment & $\varepsilon_{\mathrm{p}}$ & $\varepsilon_{\text {Ep }}$ \\
\hline Dahekou & 2.32 & -1.32 \\
\hline Weichang & 4.25 & -3.25 \\
\hline Bianqiangshan & 3.90 & -2.90 \\
\hline Goutaizi & 3.91 & -2.91 \\
\hline Xiahenan & 4.97 & -3.97 \\
\hline Boluonuo & 3.82 & -2.82 \\
\hline Hanjiaying & 5.05 & -4.05 \\
\hline Chengde & 2.66 & -1.66 \\
\hline Pingquan & 3.31 & -2.31 \\
\hline Xiabancheng & 3.36 & -2.36 \\
\hline Liying & 1.70 & -0.70 \\
\hline Kuancheng & 2.89 & -1.89 \\
\hline Hongqi & 1.93 & -0.93 \\
\hline Tumenzi & 2.78 & -1.78 \\
\hline Lengkou & 2.16 & -1.16 \\
\hline Taolinkou & 2.67 & -1.67 \\
\hline & & \\
\hline & & \\
\hline & & \\
\hline & & \\
\hline & & \\
\hline & & \\
\hline & & \\
\hline
\end{tabular}

the streamflow will increase (decrease) with an increase (decrease) in precipitation, but decrease (increase) with an increase (decrease) in $E_{p}$. Furthermore, a value of $\rho_{P, Q}$ greater than $\rho_{\mathrm{Ep}, \mathrm{Q}}$ for the Luan River basin indicates that the impact of precipitation on streamflow is more important than that of $\mathrm{E}_{\mathrm{p}}$. The correlation coefficient between precipitation and $E_{p}\left(\rho_{P, E p}\right)$ is statistically significant at the 0.01 level, indicating that the interactions between precipitation and $\mathrm{E}_{\mathrm{p}}$ are stronger. Eliminating the effects of $\mathrm{E}_{\mathrm{p}}$ (precipitation) on streamflow, the partial correlation

Table 3. Coefficients of correlation and partial correlation among annual precipitation, potential evapotranspiration, and streamflow.

\begin{tabular}{|c|l|}
\hline Coefficients & Value \\
\hline$\rho_{\mathrm{P}, \mathrm{Ep}}$ & $-0.57^{* *}$ \\
\hline$\rho_{\mathrm{P}, \mathrm{Q}}$ & $0.85^{* *}$ \\
\hline$\rho_{\mathrm{Ep}, \mathrm{Q}}$ & $-0.53^{* *}$ \\
\hline$\rho_{\mathrm{P}, \mathrm{Q}-\mathrm{Ep}}$ & $0.83^{* *}$ \\
\hline$\rho_{\mathrm{Ep}, \mathrm{Q}-\mathrm{P}}$ & -0.12 \\
\hline
\end{tabular}

$\rho_{\mathrm{PEP}}$ : correlation coefficient of $\mathrm{P}$ and $\mathrm{E}_{\mathrm{p}} ; \rho_{\mathrm{P}, \mathrm{Q}}$ : correlation coefficients of $\mathrm{P}$ and $\mathrm{Q} ; \rho_{\mathrm{Ep}, \mathrm{O}}$ : correlation coefficients of $\mathrm{E}_{\mathrm{p}}$ and Q; $\rho_{\mathrm{P}, \mathrm{Q}-\mathrm{Ep}}$ represents the partial correlation coefficient of $\mathrm{Q}$ and $\mathrm{P} ; \rho_{\mathrm{Ep}, \mathrm{Q}-\mathrm{P}}$ represents the partial correlation coefficient of $\mathrm{Q}$ and $\mathrm{E}_{\mathrm{p}}$

${ }^{* *}$ Correlation coefficient is statistically significant at the 0.01 level according to Pearson's test

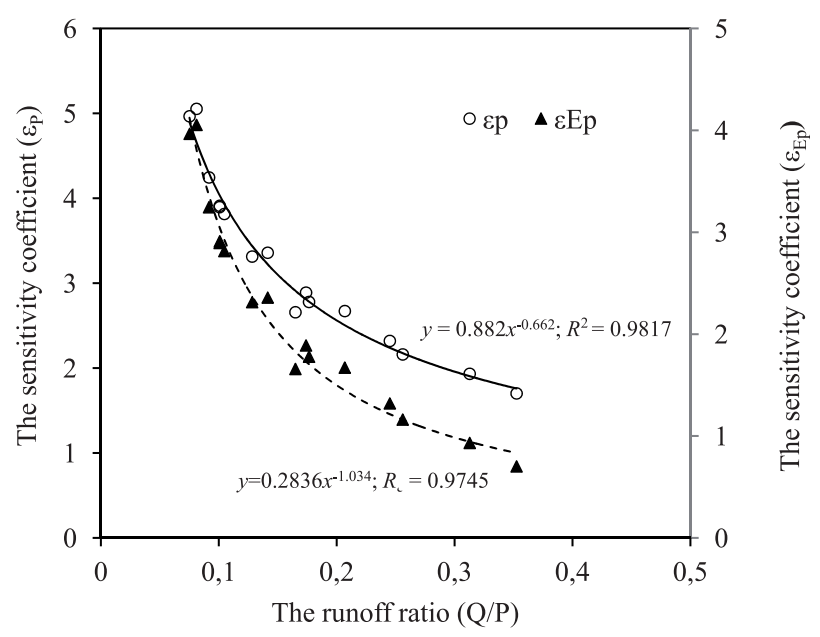

Fig. 4. The relationship between the sensitivity coefficient $\varepsilon_{p}, \varepsilon_{E p}$, and $Q / P$.

coefficients $\rho_{\mathrm{P}, \mathrm{Q}-\mathrm{Ep}}\left(\rho_{\mathrm{Ep}, \mathrm{Q}-\mathrm{P}}\right)$ between precipitation and $\mathrm{Q}$ (between $\mathrm{E}_{\mathrm{p}}$ and $\mathrm{Q}$ ) are also listed in Table 3. As observed from the table, the differences between $\rho_{\mathrm{P}, \mathrm{Q}}$ and $\rho_{\mathrm{P}, \mathrm{Q}-\mathrm{Ep}}$ are smaller, while the differences between $\rho_{\mathrm{Ep}, \mathrm{Q}}$ and $\rho_{\mathrm{Ep}, \mathrm{Q}-\mathrm{P}}$ are greater.

Fig. 4 shows the relationship between the relative $\varepsilon_{\mathrm{p}}$ and runoff ratio $(\mathrm{Q} / \mathrm{P})$. As shown, the relationship is significantly nonlinear and negative $\left(\mathrm{Y}=0.882 \mathrm{x}^{-0.662}\right.$, $\mathrm{R}^{2}=0.9817$ ), implying that the smaller the runoff ratio of a given basin, the larger the $\varepsilon_{\mathrm{p}}$. Fig. 4 also shows the negative correlation between the absolute values of the relative $\varepsilon_{\mathrm{Ep}}$ and the values of runoff ratio $(\mathrm{Q} / \mathrm{P})$. Because

Table 4. Elasticity of the aridity index to streamflow.

\begin{tabular}{|c|c|}
\hline Catchment & $\varepsilon_{\phi}$ \\
\hline Dahekou & -1.78 \\
\hline Weichang & -3.4 \\
\hline Bianqiangshan & -3.08 \\
\hline Goutaizi & -2.75 \\
\hline Xiahenan & -3.55 \\
\hline Boluonuo & -2.9 \\
\hline Hanjiaying & -3.35 \\
\hline Chengde & -2.2 \\
\hline Pingquan & -2.31 \\
\hline Xiabancheng & -2.54 \\
\hline Liying & -1.68 \\
\hline Kuancheng & -2.42 \\
\hline Hongqi & -1.91 \\
\hline Tumenzi & -2.39 \\
\hline Lengkou & -1.99 \\
\hline Taolinkou & -2.27 \\
\hline
\end{tabular}


$\varepsilon_{\mathrm{p}}+\varepsilon_{\mathrm{Ep}}=1$ [39] and $\varepsilon_{\mathrm{Ep}}$ is a negative value, a larger $\varepsilon_{\mathrm{p}}$ indicates a larger $\varepsilon_{\mathrm{Ep}}$, meaning that a basin with a low streamflow will be more sensitive to climatic variation.

\section{The Sensitivity of Streamflow to the Aridity Index}

The aridity index is a function of precipitation and potential evaporation and represents the interaction between energy and water limitation on a catchment streamflow. This index can be used as a representative indicator to estimate the impact of climatic variation on streamflow [17]. The sensitivities coefficient of streamflow to the aridity index for all catchments in the Luan River basin are listed in Table 4, and the values of $\varepsilon_{\phi}$ for the various catchments varied from -1.68 to -3.55 , with a mean of -2.53 , which indicated that streamflow in the Luan River basin would decrease by $25.3 \%$ with a $10 \%$ increase in the aridity index.

It should also be noted that the annual sensitivity coefficient of streamflow to the aridity index was not constant, and the absolute annual value of the sensitivity coefficient was high during the period from 1960 to 2000. This finding suggests that the streamflow in the basin became increasingly sensitive to the change in aridity index during the study period. In addition, Fig. 5 shows the negative correlation between the absolute values of the sensitivity coefficients and the values of the runoff ratio $(\mathrm{Q} / \mathrm{P})\left(\mathrm{Y}=1.0828 \mathrm{x}^{-0.441}, \mathrm{R}^{2}=0.9207\right)$. The absolute values of the sensitivity coefficients tended to decrease with an increase in the runoff ratio. Therefore, these results suggest that a more arid area experiences less rainfall and has a higher dry index, and that a catchment with a low streamflow is more sensitive to climatic variation.

\section{Discussion}

Two principal methods, hydrological modelling and climate elasticity, are widely used for the quantitative evaluation of the effects of climate variation on streamflow

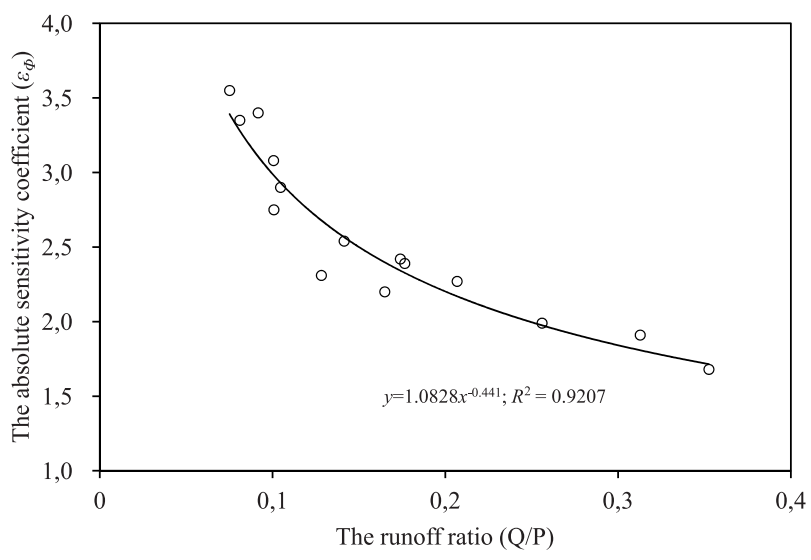

Fig. 5. The relationship between the absolute value of sensitivity coefficient $\left|\varepsilon_{\phi}\right|$ and $Q / P$. in different regions of the world. The physically based hydrological models are able to represent the complex spatial and temporal variations in evapotranspiration, soil moisture, and streamflow [20], and this method is by far the most common. However, this approach has uncertainties in the structure and the parameters of the models and may sometimes lead to a significant bias in reflecting the response of streamflow to climate change if the model is not well validated [40]. As an alternative, the method based on climate elasticity of streamflow has been tested and determined to be relatively more effective and simpler than hydrological modelling in several studies, and this method yields a general streamflow change with fewer data and parameters [13, 23-24, 34]. However, interactions between precipitation and $\mathrm{E}_{\mathrm{p}}$ and the original climate elasticity of streamflow do not effectively reflect the relationship of streamflow with precipitation and $E_{p}$. Therefore, to obtain more accurate and reasonable results in this study, we estimated the impact of climate change on streamflow using a modified climate elasticity method for streamflow as proposed by [18] Sun et al.

Changes in precipitation and $\mathrm{E}_{\mathrm{p}}$ can influence the annual streamflow. In any watershed, from a water balance perspective, the annual streamflow depends on the difference between the annual amount of precipitation and $E_{p}$. In the present study, the ratio of the sensitivity coefficient of streamflow to $\mathrm{P}$ (3.23) is larger than the ratio of streamflow to $E_{p}(-2.23)$, which indicates that the basin is more sensitive to precipitation, which has a greater capacity to impact the streamflow. As shown in Table 3, the partial correlation results indicate that the effects of precipitation on streamflow are independently related to the lesser effects of $E_{p}$, while the effects of $E_{p}$ on streamflow depend on the greater precipitation effects. All of the results of this study are similar to those of previous studies [41-42]; the potential effects of the available water (precipitation) on streamflow are greater, while the potential evapotranspiration (which reflects the energy conditions) has a smaller effect. This study revealed a strong negative correlation between $\varepsilon_{\mathrm{p}}\left(\left|\varepsilon_{\mathrm{Ep}}\right|\right)$ and the runoff coefficient (Fig. 4), and $\varepsilon_{\mathrm{p}}\left(\left|\varepsilon_{\mathrm{Ep}}\right|\right)$ is inversely related to the runoff coefficient, with the same result obtained for $\left|\varepsilon_{\phi}\right|$. This relationship indicates that streamflow is more sensitive to climatic variation with a low runoff coefficient; that is, basins with low streamflow are more sensitive to climatic variation than basins with high streamflow, which is similar to the findings of previous studies [17, 24, 4344].

On the basin scale, the response of streamflow to climate reflected the complex interactions among climate, vegetation, soil, and hydrological processes, and such interactions depend on many factors. Moreover, in addition to the effects of climate change on streamflow, human activities such as land reclamation, soil, and water conservation engineering and other activities can significantly affect the streamflow. Although human activity may also play a role in changing the annual streamflow, it was not considered in the present study. Further research is needed to explore the impact of 
human activity on streamflow in the Luan River basin. Nevertheless, determining the response of streamflow to climate change and human activity remains a difficult task in ecohydrology due to the complex feedback between hydrological processes and watershed characteristics. Furthermore, the regional impacts of climate change and human activity on hydrology vary from place to place and must be investigated on a local scale.

\section{Conclusion}

Changes in streamflow are an important part of the hydrological cycle and are affected by many factors, and a complicated feedback to climate change exists. Because of the intimate linkage between hydrology and climate, this relationship can be used as an indicator of climate change. In this study, the concept of the climate elasticity of streamflow has been applied to quantify the sensitivity of streamflow to climate. The findings can be summarized as follows:

1) Precipitation and $E_{p}$ are the most important meteorological variables influencing changes in streamflow. Streamflow was positively correlated with precipitation but negatively correlated with $\mathrm{E}_{\mathrm{p}}$, and the streamflow-precipitation relationships were stronger than the streamflow- $\mathrm{E}_{\mathrm{p}}$ relationships.

2) The average $\varepsilon_{\mathrm{p}}$ and $\varepsilon_{\mathrm{Ep}}$ were 3.23 and -2.23 , respectively, which indicated that a $10 \%$ increase in precipitation or potential evapotranspiration would lead to a $32.3 \%$ increase or a $22.3 \%$ decrease in streamflow, respectively. Additionally, the average $\varepsilon_{\phi}$ was -2.53 , which indicated that streamflow would decrease by $25.3 \%$ with a $10 \%$ increase in the aridity index.

3) The relative $\varepsilon_{\mathrm{p}}\left(\left|\varepsilon_{\mathrm{Ep}}\right|\right)$ and the runoff ratio $(\mathrm{Q} / \mathrm{P})$ showed a significantly nonlinear and negative relationship, a similar result as for $\left|\varepsilon_{\phi}\right|$. All these results suggest that the more arid the area, the less rainfall occurs and the higher the aridity index, and basins with low streamflow are more sensitive to climatic variation than basins with higher streamflow.

\section{Acknowledgements}

This work was supported by the National Science-technology Support Plan Projects (2015BAD07B030302) and the Qinghai Province Natural Science Foundation Project (2015-ZJ-902). The first author would like to thank the two anonymous reviewers for their thoughtful recommendations, which have greatly improved the manuscript.

\section{References}

1. CAO Z., LIU J., LUAN Y., LI Y., MA M., XU J., HAN S. Distribution and ecosystem risk assessment of polycyclic aromatic hydrocarbons in the Luan River, China. Ecotoxicology 19 (5), 827, 2010.
2. WANG W., SHAO Q., YANG T., PENG S., XING W., SUN F., LUO Y. Quantitative assessment of the impact of climate variability and human activities on runoff changes: a case study in four catchments of the Haihe River Basin, China. Hydrological Processes 27 (8), 1158, 2013.

3. RODRIGUEZ-ITURBE I. Ecohydrology: a hydrologic perspective of climate-soil-vegetation dynamies. Water Resour. Res. 36 (1), 3, 2000.

4. RODRIGUEZ-ITURBE I., PORPORATO A., LAIO F., RIDOLFI L. Plants in water-controlled ecosystems: active role in hydrologic processes and response to water stress. Adv. Water Resour. 24 (7), 695, 2001.

5. RODRIGUEZ-ITURBE I., PORPORATO A. Ecohydrology of Water-Controlled Ecosystems: Soil Moisture and Plant Dynamics, Cambridge: Cambridge University Press, 2007.

6. GUO S., WANG J., XIONG L., YING A., LI D. A macroscale and semi-distributed monthly water balance model to predict climate change impacts in China. J. Hydrol. 268 (1), $1,2002$.

7. CHEN H., GUO S., XU C., SINGH V.P. Historical temporal trends of hydro-climatic variables and runoff response to climate variability and their relevance in water resource management in the Hanjiang Basin. J. Hydrol. 344 (3), 171, 2007.

8. MILLY P.C.D., BETANCOURT J., FALKENMARK M., HIRSCH R.M., KUNDZEWICZ Z.W., LETTENMAIER D.P., STOUFFER R.J. Stationarity is dead: whither water management? Science 319 (5863), 573, 2008.

9. IMMERZEEL W.W., VAN BEEK L.P., BIERKENS M.F. Climate change will affect the asian water towers. Science 328 (5984), 1382, 2010.

10. XU K., MILLIMAN J.D., XU H. Temporal trend of precipitation and runoff in major Chinese rivers since 1951. Global Planet. Change 73 (3), 219, 2010.

11. LI L., ZHANG L., WANG H., WANG J., YANG J., JIANG D., LI J., QIN D. Assessing the impact of climate variability and human activities on streamflow from the Wuding River Basin in China. Hydrological Processes 21 (25), 3485, 2007.

12. CONG Z., YANG D., GAO B., YANG H., HU H. Hydrological trend analysis in the yellow river basin using a distributed hydrological model. Water Resour. Res. 45 (7), 335, 2009.

13. MA H., YANG D., TAN S.K., GAO B., HU Q. Impact of climate variability and human activity on streamflow decrease in the Miyun Reservoir catchment. J. Hydrol. 389 (3), 317, 2010.

14. WANG J., HONG Y., GOURLEY J., ADHIKARI P., LI L., SU F. Quantitative assessment of climate change and human impacts on long-term hydrologic response: a case study in a sub-basin of the Yellow River, China. Int. J. Climatol. 30 (14), 2130, 2010.

15. FENG X., VICO G., PORPORATO A. On the effects of seasonality on soil water balance and plant growth. Water Resour. Res. 48 (5), 213, 2012.

16. DU J., HE F., ZHANG Z., SHI P.J. Precipitation change and human impacts on hydrologic variables in Zhengshui River Basin, China. Stoch. Environ. Res. Risk Assess 25 (7), 1013, 2011.

17. LIU X., LIU W., XIA J. Comparison of the streamflow sensitivity to aridity index between the Danjiangkou Reservoir Basin and Miyun Reservoir Basin, China. Theor. Appl. Climatol. 111 (3-4), 683, 2013.

18. SUN S., CHEN H., JU W., SONG J., ZHANG H., SUN J., FANG Y. Effects of climate change on annual streamflow using climate elasticity in Poyang Lake Basin, China. Theor. Appl. Climatol. 112 (1-2), 169, 2013. 
19. ARORA V.K. The use of the aridity index to assess climate change effect on annual runoff. J. Hydrol. 265 (1), 164, 2002.

20. SANKARASUBRAMANIAN A., VOGEL R.M., LIMBRUNNER J.F. Climate elasticity of streamflow in the United States. Water Resour. Res. 37 (6), 1771, 2001.

21. LIU X., LIU C., LUO Y., ZHANG M., XIA J. Dramatic decrease in streamflow from the headwater source in the central route of China's water diversion project: climatic variation or human influence? J. Geophys. Res. 117 (D6), 2012.

22. SCHAAKE J.C. From climate to flow. In Climate, Change, Water Resources, Waggoner, P.E., Ed., John Wiley: New York, pp. 177, 1990.

23. FU G., CHARLES S.P., CHIEW F.H.S. A two-parameter climate elasticity of streamflow index to assess climate change effects on annual streamflow. Water Resour. Res. 43 (11), 2578, 2007.

24. ZHENG H., ZHANG L., ZHU R., LIU C., SATO Y., FUKUSHIMA Y. Responses of streamflow to climate and land surface change in the headwaters of the Yellow River Basin. Water Resour. Res. 45 (7), 641, 2009.

25. DOMAGALSKI J., LIN C., LUO Y., KANG J., WANG S.M., BROWN L.R., MUNN M.D. Eutrophication study at the Panjiakou-Daheiting Reservoir system, Northern Hebei Province, People's Republic of China: chlorophyll-a model and sources of phosphorus and nitrogen. Agric. Water Manag. 94 (1-3), 43, 2007.

26. PENMAN H.L., Natural evaporation from open water, bare soil and grass. Proc. R. Soc. Lond. A Math Phys. Sci. 193 (1032), 120, 1948.

27. SHUTTLEWORTH W.J. Evaporation in: Maidment, DR. Handbook of Hydrology. McGraw-Hill, New York, America. pp. 4.1-4.53, 1993.

28. DONOHUE R.J., MCVICAR T.R., RODERICK M.L. Assessing the ability of potential evaporation formulations to capture the dynamics in evaporative demand within a changing climate. J. Hydrol. 386 (1-4), 186, 2010.

29. YIN Y., WU S., ZHENG D., YANG Q. Radiation calibration of FAO56 Penman-Monteith model to estimate reference crop evapotranspiration in China. Agric. Water Manag. 95 (1), 77, 2008.

30. MANN H.B. Nonparametric tests against trend. Econometrika 13 (3), 245, 1945.

31. KENDALL M.G. Rank Correlation Methods, London: C. Griffin, 1948.

32. HAMED K.H. Trend detection in hydrologic data: the Mann-
Kendall Trend Test under the scaling hypothesis. J. Hydrol. 349 (3-4), 350, 2008.

33. LIANG L., LI L., LIU Q. Temporal variation of reference evapotranspiration during 1961-2005 in the Taoer River Ba$\sin$ of Northeast China. Agric. Forest Meteorol. 150 (2), 298, 2010.

34. HU S., LIU C., ZHENG H., WANG Z., YU J. Assessing the impacts of climate variability and human activities on streamflow in the water source area of Baiyangdian Lake. J. Geogr. Sci. 22 (5), 895, 2012.

35. LIU H., LI Y., JOSEF T., ZHANG R., HUANG G. Quantitative estimation of climate change effects on potential evapotranspiration in Beijing during 1951-2010. J. Geogr. Sci. 24 (1), 93, 2014.

36. BUDYKO M.I. Evaporation under Natural Conditions, English translation by IPST: Gidrometeorizdat, Leningrad, Jerusalem, 1948.

37. ZHANG L., DAWES W.R., WALKER G.R. Response of mean annual evapotranspiration to vegetation changes at catchment scale. Water Resour. Res. 37 (3), 701, 2001.

38. DOOGE J.C.I. Sensitivity of runoff to climate change: a Hortonian approach. Bull Am Meteorol Soc 73 (12), 2013, 1992.

39. PEEL M.C., MCMAHON T.A., FINLAYSON B.L. Vegetation impact on mean annual evapotranspiration at a global catchment scale. Water Resour. Res. 46 (9), 2095, 2010.

40. LEGESSE D., VALLET-COULOMB C., GASSE F. Hydrological response of a catchment to climate and land use changes in tropical Africa: case study South Central Ethiopia. J. Hydrol. 275 (1/2), 67, 2003.

41. SUN S.L., CHEN H.S., JU W.M., SONG J., LI J.J., REN Y.J., SUN J. Past and future changes of streamflow in Poyang Lake Basin, South Eastern China. Hydrol. Earth Syst. Sci. 16 (7), 2005, 2012.

42. ZHAO G., HÖRMANN G., FOHRER N., ZHANG Z., ZHAI J. Streamflow trends and climate variability impacts in Poyang Lake Basin, China. Water Resour. Manag. 24 (4), 689, 2010.

43. RENNER M., SEPPELT R., BERNHOFER C. Evaluation of water-energy balance frameworks to predict the sensitivity of streamflow to climate change. Hydrol. Earth Syst. Sci. 16 (5), 1419, 2012.

44. WANG H., YU X. Sensitivity Analysis of Climate on streamflow in North China. Theor. Appl. Climatol. 119 (1-2), 391, 2015. 